\title{
Rancang Bangun Aplikasi E-Voting Pemilihan Badan Eksekutif Mahasiswa Universitas Katolik Santo Thomas Berbasis Android
}

\author{
Lena Siagian ${ }^{1}$, Masdiana Sagala ${ }^{2}$ \\ ${ }^{1,2}$ Universitas Katolik Santo Thomas Medan, Jl. Setiabudi No. 479 F Tanjungsari, Medan, Indonesia
}

\section{ARTICLE INFORMATION}

Received: September, 27, 2020

Revised: September, 29, 2020

Available online: Oktober,31 2020

\section{KEYWORDS}

Five words maximum, comma separated

AHP, ANALYTICAL HiERARCHY PROCESS,

BEM , EVOTING

Phone: +62 852-9758-2812

E-mail: diana.sg16@gmail.com

\section{A B $\mathbf{S}$ T $\mathbf{R}$ A $\mathbf{K}$}

\begin{abstract}
Organisasi kampus dapat dikategorikan ke dalam dua jenis, yaitu organisasi mahasiswa eksternal kampus dan internal kampus. Organisasi internal kampus adalah organisasi mahasiswa yang melekat pada pribadi kampus atau universitas dan memiliki kedudukan resmi di lingkungan perguruan tinggi seperti Badan Eksekutif Mahasiswa (BEM) atau dengan nama lain Badan Perwakilan Mahasiswa Universitas atau Badan Permusyawaratan Mahasiswa Universitas (BPMU). Dimana pemilihan BEM atau BPMU setiap tahunnya menjadi moment yang sangat penting dan dinantikan. Biasanya pemilihan BEM atau BPMU dilakukan dengan cara pemungutan suara yang mana masih memiliki banyak kelemahan/kekurangan diantaranya yaitu penghitungan suara yang lambat, kesalahan dalam penghitungan, dan kecurangan dalam pemungutan suara. Untuk mengurangi masalah dalam pemungutan suara maka dibangunlah aplikasi E-Voting pemilihan BEM berbasis android dengan menggunakan metode AHP.
\end{abstract}

\section{PENDAHULUAN}

Organisasi mahasiswa adalah organisasi yang bergerak dan beranggotakan mahasiswa dikampus. Secara umum, organisasi kampus dapat dikategorikan ke dalam dua jenis, yaitu organisasi mahasiswa eksternal kampus dan internal kampus. Organisasi eksternal kampus merupakan organisasi mahasiswa yang beranggotakan mahasiswa dan aktivitasnya berada di luar lingkup universitas atau perguruan tinggi. Organisasi internal kampus adalah organisasi mahasiswa yang melekat pada pribadi kampus atau universitas dan memiliki kedudukan resmi di lingkungan perguruan tinggi. Organisasi internal kampus yang memiliki kedudukan paling tinggi yaitu Badan Eksekutif Mahasiswa (BEM) atau dengan nama lain Badan Perwakilan Mahasiswa Universitas atau Badan Permusyawaratan Mahasiswa Universitas (BPMU).

Pentingnya peranan dan fungsi BEM atau BPMU dalam lingkungan kampus membuat pemilihan Ketua BEM atau BPMU setiap tahunnya menjadi moment yang sangat penting bagi mahasiswa. Demikian juga dengan Universitas Katolik Santo Thomas, pemilihan Ketua BEM atau BPMU adalah moment yang sangat penting dan dinantikan. Biasanya pemilihan Ketua BEM atau BPMU pada Universitas Katolik Santo Thomas dilakukan dengan cara pemungutan suara. Pemungutan suara dilakukan dengan cara menyediakan kertas suara per Fakultas di TPS masing-masing[1][2].

Pemilihan BEM atau BPMU pada Universitas Katolik Santo Thomas yang selama ini dilakukan dengan cara pemungutan suara memiliki banyak kelemahan/kekurangan diantaranya yaitu penghitungan suara yang lambat, kesalahan dalam penghitungan, dapat dilakukan kecurangan dengan cara menggunakan kertas yang belum digunakan untuk calon BEM atau BPMU tertentu dan kelemahan lainnya yaitu hal ini menghabiskan banyak dana karena harus menyediakan kertas suara untuk setiap mahasiswa aktif Universitas Katolik Santo Thomas.

Skema E-Voting adalah satu set protokol yang menjaga keamanan atau kerahasiaan pemilih dalam melakukan pemilihan serta interaksi dengan panitia pemilihan dan perhitungansuara [3], [4]. E-Voting biasanya dibedakan menjadi dua tipe yaitu online (misalnya via internet) dan off line (menggunakan mesin perhitungan suara atau kertas suara). Android adalah susunan dari beberapa perangkat lunak (software stack). Stack ini secara umum meliputi sistem operasi, middleware, dan aplikasi-aplikasi kunci. Android pada awalnya tidak dikembangkan oleh google, melainkan dikembangkan oleh sebuah perusahaan bernama Android Inc. Karena google melihat banyaknya user yang online dengan perangkat mobile, maka google melihat peluang yang sangat besar bahwa perangkat mobile ini memiliki masa depan yang cerah, sehingga Android Inc diakuisi oleh Google pada tahun 2005[5], [6].

Analytical hierarchy process atau proses hirarki analitik, yang biasa di sebut dengan AHP, pertama kali dikembangkan oleh Thomas L. Saaty, seorang ahli matematikadari University of Pittsburg, Amerika Serikat, pada tahun 1970-an. AHP pada dasarnya di desain untuk menangkap secara rasional persepsi orang yang berhubungan erat dengan permasalahan tertentu melalui prosedur yang di desain untuk sampai pada skala preferensi diantara berbagai set alternative[7], [8]. 
Model AHP merupakan salah satu bentuk pengambilan keputusan yang pada dasarnya berusaha menutupi semua kekurangan dari model-model sebelumnya. Peralatan utama dari model ini adalah sebuah hirarki fungsional dengan input utamanya persepsi manusia. Dengann hirarki, suatu masalah yang kompleks dan tidak terstruktur dipecah dalam kelompok-kelompoknya, kemudian di atur menjadi suatu bentuk hirarki. Kelebihan dari metode AHP adalah kmampuannya yang dapat memecahkan masalah multicriterias. Hal ini disebabkan oleh fleksibelitasnya yang tinggi terutama dalam pembuatan hirarkinya. Sifat fleksibel tersebut membuat model AHP dapat menangkap beberapa tujuan dan beberapa kriteria sekaligus dalam sebuah model atau hirarki[9], [10].

Android adalah susunan dari beberapa perangkat lunak (software stack). Stack ini secara umum meliputi sistem operasi, middleware, dan aplikasi-aplikasi kunci. Android pada awalnya tidak dikembangkan oleh google, melainkan dikembangkan oleh sebuah perusahaan bernama Android Inc. Karena google melihat banyaknya user yang online dengan perangkat mobile, maka google melihat peluang yang sangat besar bahwa perangkat mobile ini memiliki masa depan yang cerah, sehingga Android Inc diakuisi oleh Google pada tahun 2005 [11].

Dari permasalahan diatas penulis memberikan solusi yaitu dengan membangun aplikasi E-Voting pemilihan Badan Eksekutif Mahasiswa Universitas Katolik Santo Thomas berbasis android. Electronic Voting adalah suatu metode pemungutan suara dan penghitungan suara dalam suatu pemilihan dengan menggunakan perangkat elektronik. Tujuan dari Electronic Voting adalah menyelenggarakan pemungutan suara dengan biaya hemat dan penghitungan suara yang cepat dengan menggunakan sistem yang aman dan mudah untuk dilakukan audit. Dengan E-Voting, perhitungan suara akan lebih cepat, bisa menghemat biaya pencetakan surat suara, pemungutan suara lebih sederhana, dan peralatan dapat digunakan berulang kali[12]. Diharapkan dengan adanya Aplikasi E-Voting Pemilihan Ketua Badan Eksekutif Mahasiswa Universitas Katolik Santo Thomas Berbasis Adroid dapat memudahkan perhitugan suara, lebih teliti dan akurat serta dapat meminimalisir kecurangan hak suara. Selain itu mahasiswa dapat memilih BEM atau BPMU yang diinginkan dengan menggunakan smartphone dimanapun mereka berada.

\section{METODE PENELITIAN}

Adapun metodologi penelitian penelitian adalah sebagai berikut[13]:

1. Observasi

Metode observasi / Pengamatan yang dilakukan dengan cara mengamati semua kegiatan yang berhubungan dengan proses pemilihan yang dilakukan dengan cara Voting atau dengan pengambilan suara yang terbanyak, termasuk dalam proses Pemilihan Badan Eksekutif Mahasiswa Unika Santo Thomas.

2. Wawancara

Metode pengumpulan data yang dilakukan dengan cara tanya jawab secara langsung kepada anggota Badan Eksekutif Mahasiswa yang bertugas sebagai panitia pemilihan calon Badan Eksekutif Mahasiswa yang baru tentang langkah-langkah pemilihan Badan Eksekutif Mahasiswa yang baru dan data-data apa saja yang berhubungan dengan pimilihan Badan Eksekutif Mahasiswa.

3. Studi Pustaka

Studi Pustaka yaitu penelitian yang dilakukan dengan cara membaca dan mempelajari buku-buku dan jurnal-jurnal yang berkaitan dengan masalah yang akan di bahas.

Metode AHP dengan dasar berpikirnya metode AHP adalah proses membentuk skor secara numerik untuk menyusun rangking setiap alternatif keputusan berbasis pada bagaimana sebaiknya alternatif itu dicocokkan dengan criteria pembuat keputusan. Adapun langkah-langkah metode AHP adalah[14], [15]:

1. Menentukan jenis-jenis kriteria yang akan menjadi persyaratan calon pejabat struktural.

2. Menyusun kriteria-kriteria tersebut dalam bentuk matriks berpasangan.

3. Menjumlah matriks kolom.

4. Menghitung nilai elemen kolom kriteria dengan rumus masing-masing elemen kolom dibagi dengan jumlah matriks kolom.

5. Menghitung nilai prioritas kriteria dengan rumus menjumlah matriks baris hasil langkah ke 4 dan hasilnya 5 dibagi dengan jumlah kriteria[16].

6. Menentukan alternatif-alternatif yang akan menjadi pilihan.

7. Menyusun alternatif-alternatif yang telah ditentukan dalam bentuk matriks berpasangan untuk masing-masing kriteria. Sehingga akan ada sebanyak $\mathrm{n}$ buah matriks berpasangan antar alternatif.

8. Masing-masing matriks berpasangan antar alternative sebanyak $\mathrm{n}$ buah matriks, masing-masing matriksnya dijumlah per kolomnya.

9. Menghitung nilai prioritas alternatif masing-masing matriks berpasangan antar alternatif dan langkah 5.

10. Menguji konsistensi setiap matriks berpasangan antar alternatif dengan rumus masing-masing elemen matriks berpasangan pada langkah 2 dikalikan dengan nilai prioritas kriteria 


\section{HASIL DAN PEMBAHASAN}

Implementasi anatar muka merupakan tahapan dalam memenuhi kebutuhan user dalam berinteraksi dengan komputer, fasilitas antar muka yang baik sangat membantu pemakai dalam memahami proses yang sedang dilakukan oleh sistem tersebut dan dapat meningkatkan kinerja sistem[17]. Berikut adalah implementasi antar muka Aplikasi E Voting pemilihan BEM Universitas Katolik Santo Thomas berbasis android.

Halaman utama merupakan tampilan utama pada saat aplikasi berjalan, dimana halaman menu utama terdapat nama judul, photo para calon BEM, SENAT setiap fakultas dan HMP setiap jurusan yang ada di Universitas Katolik Santo Thomas dimana apabila setiap photo di klik akan muncul informasi atau profil setiap calon BEM dan ada juga tombol home dan login. Gambar halaman menu utama dapat dilihat pada gambar 1 di bawah ini.

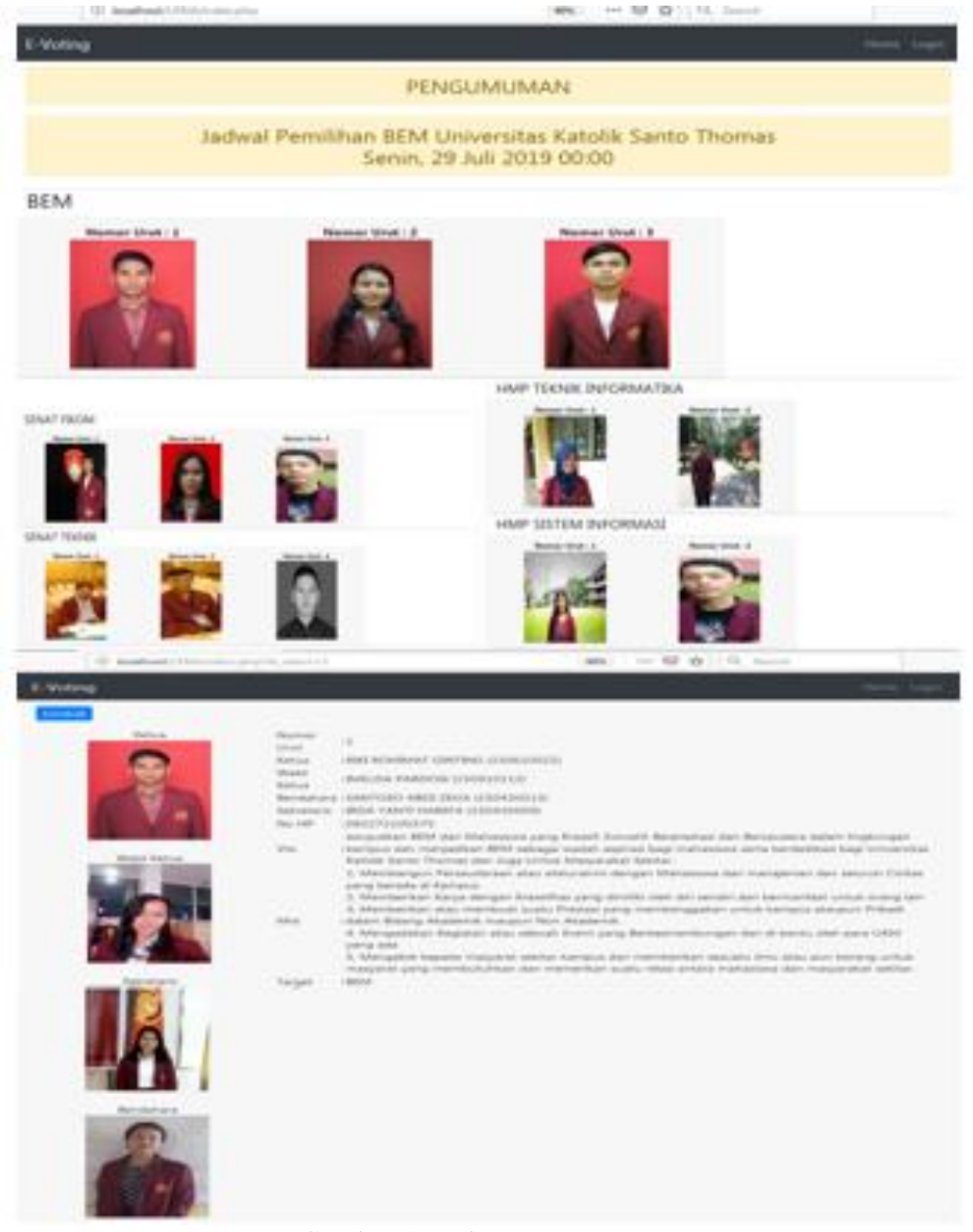

Gambar 1 Halaman Menu Utama

Halaman login merupakan halaman untuk masuk kedalam aplikasi dan melakukan aktivitas atau proses didalamnya. Pada aplikasi ini terdapat dua user atau pengguna aplikasi ini, yaitu Admin atau Panitia Pemilihan Umum Mahasiswa (PPUM). Gambar halaman login Admin dapat dilihat pada gambar V.2 dan gambar login mahasiswa dapat dilihat pada gambar 2 di bawah ini

\begin{tabular}{|l|}
\hline E-Voting \\
\hline Login \\
Username \\
Password \\
\hline Login
\end{tabular}

Gambar 2. Halaman login Admin

Rancang Bangun Aplikasi E-Voting Pemilihan Badan Eksekutif Mahasiswa Universitas Katolik Santo Thomas Berbasis Android. Oleh : Lena Siagian, Masdiana Sagala. 
Pada halaman ini terdapat menu jadwal, fakultas, jurusan, pemilihan, target, calon, syarat calon dan AHP. Halaman Utama Admin dapat di lihat pada gambar 3 di bawah ini

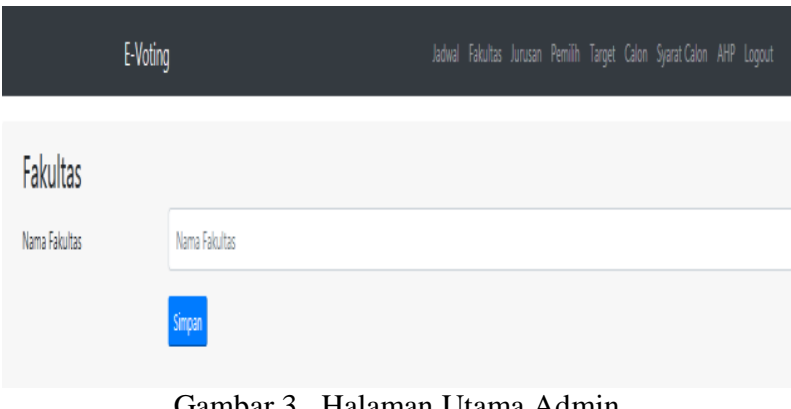

Gambar 3. Halaman Utama Admin

Halaman Jadwal merupakan halaman yang menampilan jadwal memilih di Universitas Katolik Santo Thomas dimana waktu memilih dibatasi. Untuk selengkapnya halaman Jadwal dapat dilihat pada gambar 4 di bawah ini.

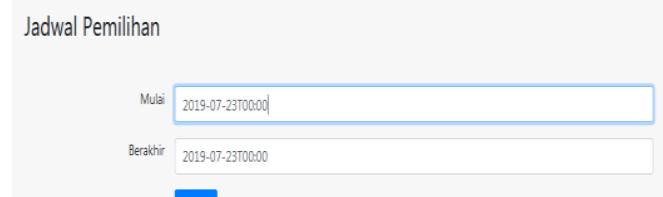

Gambar 4. Halaman Jadwal

Halaman Fakultas merupakan halaman yang menampilan data semua Fakultas yang ada di Universitas Katolik Santo Thomas. Untuk selengkapnya halaman Fakultas dapat dilihat pada gambar 5 di bawah ini.

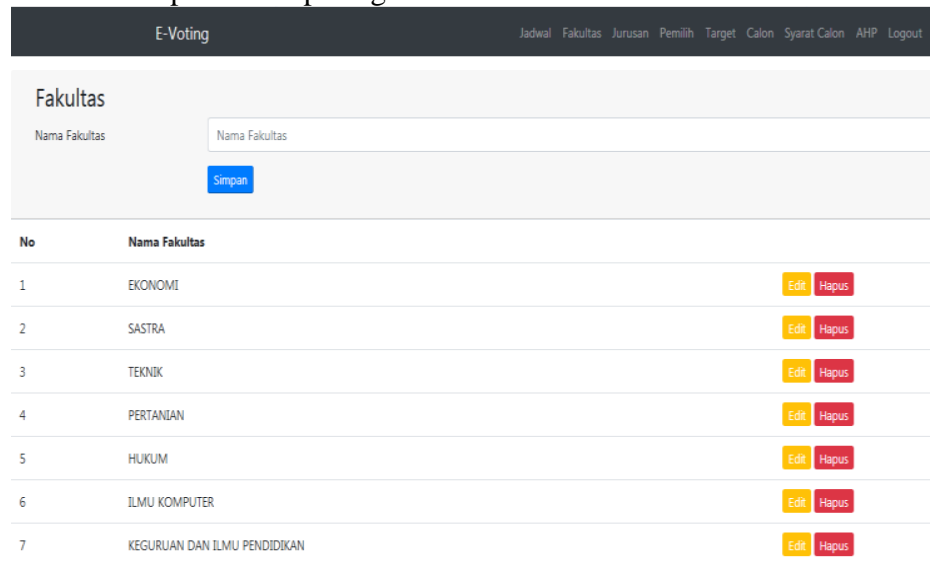

Gambar 5. Halaman Fakultas

Halaman Jurusan merupakan halaman yang menampilan data semua jurusan di setiap Fakultas yang ada di Universitas Katolik Santo Thomas. Untuk selengkapnya halaman Jurusan dapat dilihat pada gambar 6 di bawah ini.

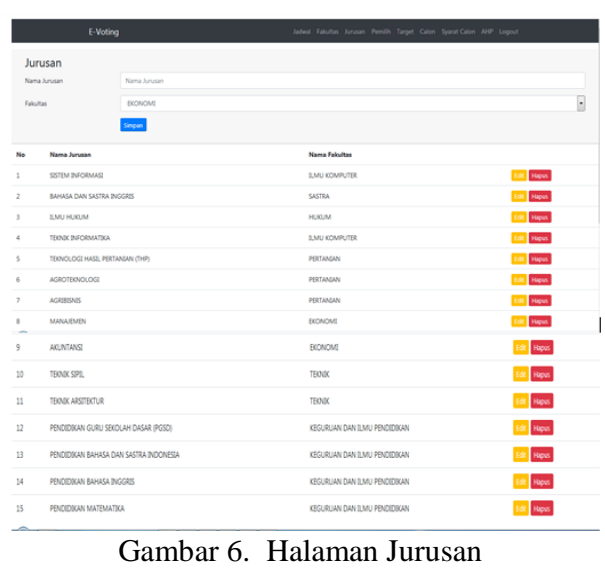

Rancang Bangun Aplikasi E-Voting Pemilihan Badan Eksekutif Mahasiswa Universitas Katolik Santo Thomas Berbasis Android. Oleh : Lena Siagian, Masdiana Sagala. 
Halaman Pemilihan merupakan halaman yang menampilan data mahasiswa yang masih aktif di Universitas Katolik Santo Thomas. Untuk selengkapnya halaman Pemilih dapat dilihat pada gambar 7 di bawah ini.

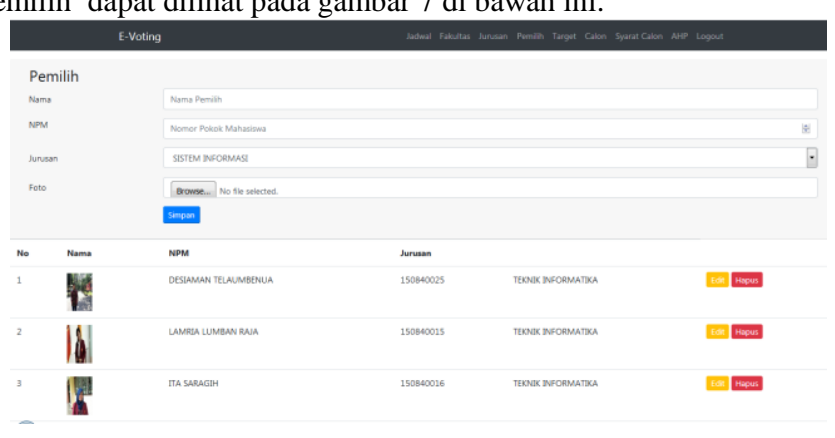

Gambar 7. Halaman Pemilih

Halaman Calon merupakan halaman yang menampilan data-data para Calon. Untuk selengkapnya Halaman Calon dapat dilihat pada gambar 8 di bawah ini..

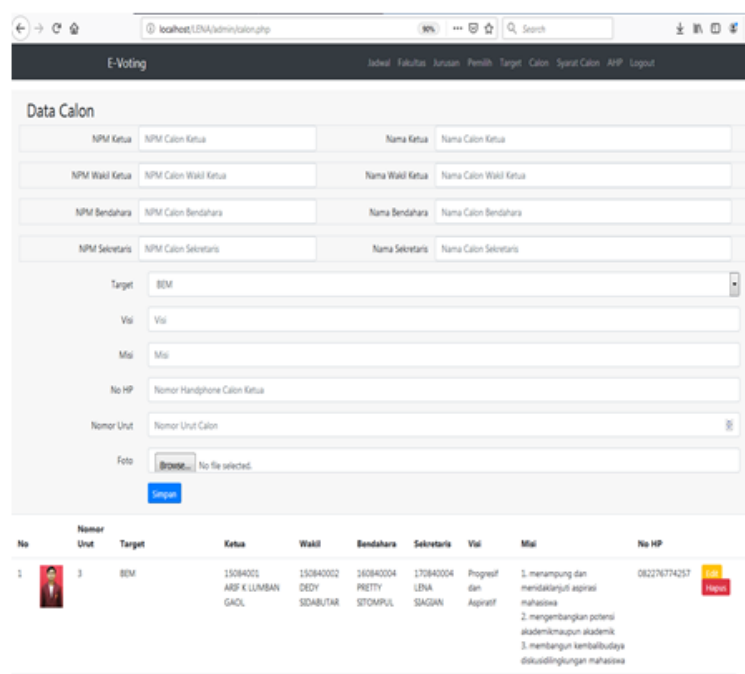

Gambar 8. Halaman Calon

Halaman Target merupakan halaman yang menampilan target dan relasi target. Untuk selengkapnya Halaman Target dapat dilihat pada gambar 9 di bawah ini.

\begin{tabular}{|c|c|c|c|c|c|}
\hline \multicolumn{2}{|r|}{ E-Voting } & \multicolumn{3}{|c|}{ 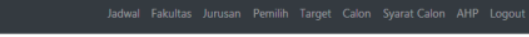 } & \\
\hline \multicolumn{3}{|c|}{$\begin{array}{l}\text { Target } \\
\text { Nama Target }\end{array}$} & \multicolumn{3}{|l|}{$\begin{array}{l}\text { Relasi Target } \\
\text { Nama Target }\end{array}$} \\
\hline \multicolumn{3}{|c|}{ Nama Target } & \multicolumn{3}{|l|}{ BEM } \\
\hline \multicolumn{3}{|c|}{ Simpan Target } & \multicolumn{3}{|l|}{ Jurusan } \\
\hline No & Target & & SISTEM INFORMASI & & $\bullet$ \\
\hline 1 & BEM & Exan Hapus & \multicolumn{3}{|l|}{ Simpan Relasi } \\
\hline 2 & SENAT FKOM & Eat Hepus & No Target & Jurusan & \\
\hline 3 & SENAT TERNAK & teas Hapus & 1 BEM & SISTEM INFORMASI & Fant \\
\hline 4 & SENAT EKONOMI & $\begin{array}{l}\text { Eat Hapus } \\
\text { Eath Hapus }\end{array}$ & $2 \quad B E M$ & TERNIIINFORMATIKA & Eaph \\
\hline 6 & SENAT PERTANIAN & Eane Hapus & 3 BEM & MANAJEMEN & Eath \\
\hline 7 & SENAT HUKUM & Eat Hapus & \multirow[t]{2}{*}{4 BEM } & \multirow[t]{2}{*}{ AKUNTANSI } & ren. \\
\hline 8 & SENAT FARULTAS KEGURUAN DAN LLMU PENDDDIKAN (FKRP) & Eat hapus & & & Hapus \\
\hline
\end{tabular}

Halaman Syarat Calon merupakan halaman yang menampilan kriteria-kriteria Calon. Untuk selengkapnya halaman syarat calon dapat dilihat pada gambar 10 di bawah ini 


\begin{tabular}{|c|c|c|c|c|c|c|c|c|c|c|}
\hline \multicolumn{3}{|c|}{ E-Voting } & \multicolumn{8}{|c|}{ 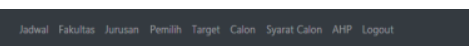 } \\
\hline \multicolumn{11}{|c|}{ Kriteria Syarat } \\
\hline No & $\mathrm{NM}$ & Nama & ks1 & ks2 & ks3 & kS4 & kss & ks6 & ks7 & \\
\hline 1 & 150410005 & AQEF K K UUMBAN GAOL & 5 & 5 & 2 & 5 & 1 & 5 & 2 & Edot \\
\hline 2 & 150600069 & RECROHBMAT ENTING & 2 & 2 & 5 & 5 & 5 & 5 & 5 & E由 \\
\hline 3 & 160110076 & ELRIDA GUITOM & 5 & 3 & 3 & 3 & 4 & 5 & 5 & EE⿱一𫝀口) \\
\hline 4 & 150210017 & PerREaA n Sembirang & 5 & 5 & s & 5 & 5 & 5 & 5 & E⿵冂卄丷 \\
\hline 5 & 150810009 & EDUY MANXX & 2 & 3 & 4 & 5 & 5 & 4 & 5 & E⿺辶⿸ \\
\hline 6 & 150910081 & HERY SPAANNG & 5 & 4 & 5 & 4 & 5 & 5 & 5 & Ede \\
\hline 7 & 160840011 & HOMAn SahHaN & 3 & 3 & 5 & 4 & 3 & 5 & 5 & EAd \\
\hline 8 & 150810013 & EM STHALOHO & 5 & 4 & 5 & 2 & 5 & 5 & 5 & EDe \\
\hline 9 & 150040016 & TIA SQRAGIH & 3 & 5 & 5 & 4 & 3 & 5 & 5 & E⿺辶力 \\
\hline 10 & 150840002 & DESAMAN TELUMBEEVUA & 5 & 5 & 3 & 5 & 5 & 5 & 5 & E⿰⿴囗十⿱一⿴⿻儿口一寸 \\
\hline 11 & 150810022 & SAFARMAN HALAWA & 5 & 5 & 5 & 5 & 5 & 5 & 5 & EAd \\
\hline 6 & .unserane & mourcure remenen & . & . & . & . & . & . & . & $m$ \\
\hline
\end{tabular}

Gambar 10 Halaman Syarat Calon

Halaman AHP merupakan halaman yang menampilan perhitungan metode AHP nya. Untuk selengkapnya Halaman AHP dapat dilihat pada gambar 11 di bawah ini.

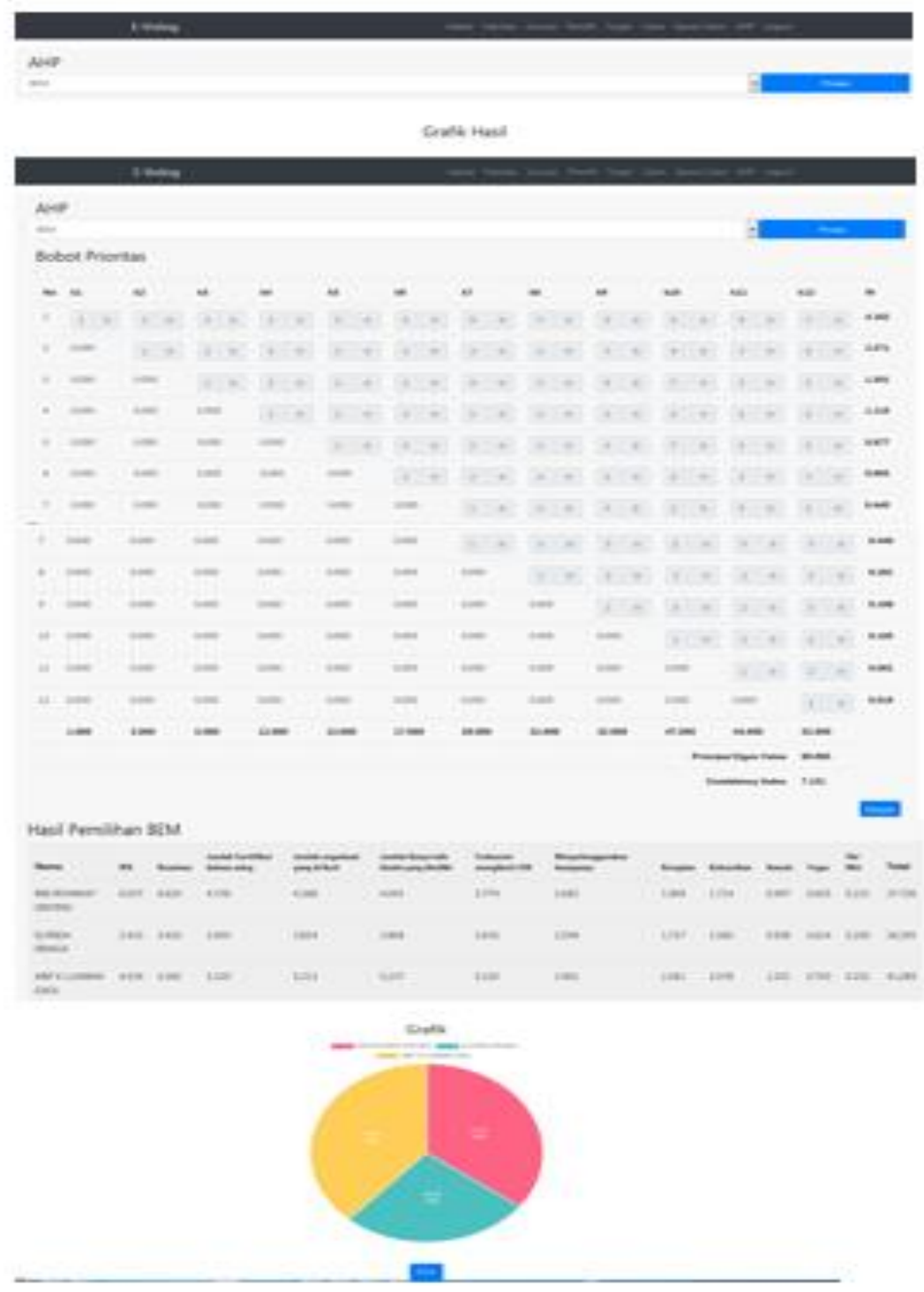

Gambar 11. Halaman AHP

Pada halaman ini terdapat menu calon dan logout. Halaman Utama pemilih dapat di lihat pada Selanjutnya Mahasiswa login menggunakan NPM, sehingga akan muncul Menu Pilihan seperti pada gambar berikut: 


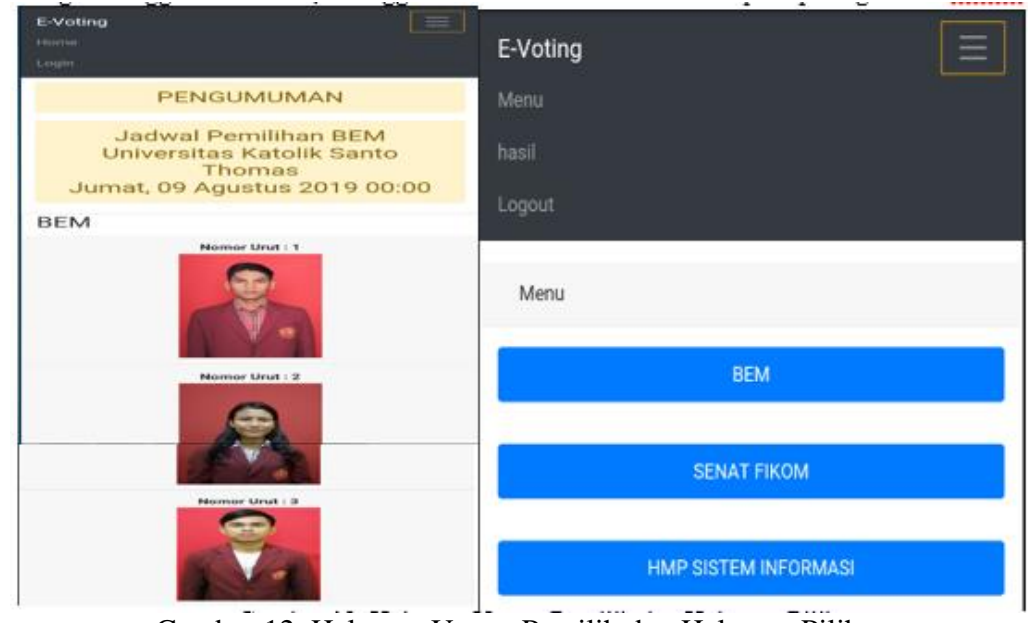

Gambar 12. Halaman Utama Pëmilih dan Ḧalaman Pilihan

Pada halaman ini mahasiswa melakukan voting. Halaman Memilih dapat di lihat pada gambar 13 di bawah ini.
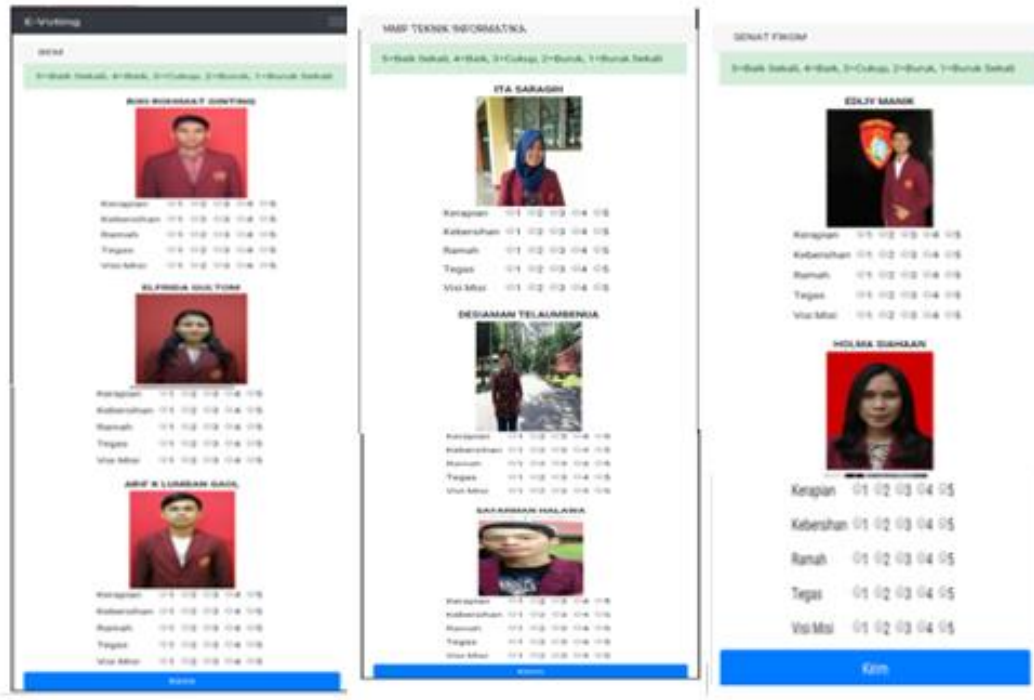

Gambar 13. Halaman Memilih

Setelah Mahasiswa selesai memilih maka Mahasiswa tidak dapat memilih lagi untuk kedua kalinya. Dan pada saat Mahasiswa melakukan pemilihan untuk kedua kalinya, akan ada pesan “Anda sudah melakukan pemilihan”. Pesan pemilihan dapat dilihat pada gambar 14 di bawah ini

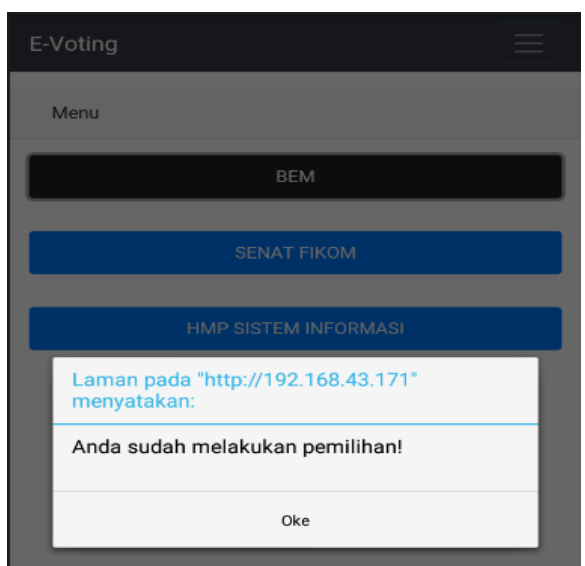

Gambar 14 Pesan Pemilihan

Pada halaman ini akan menampilkan urutan nilai setiap para calon. Tampilan hasil laporan dapat di lihat pada gambar 15 dibawah ini

Rancang Bangun Aplikasi E-Voting Pemilihan Badan Eksekutif Mahasiswa Universitas Katolik Santo Thomas Berbasis Android. Oleh : Lena Siagian, Masdiana Sagala. 


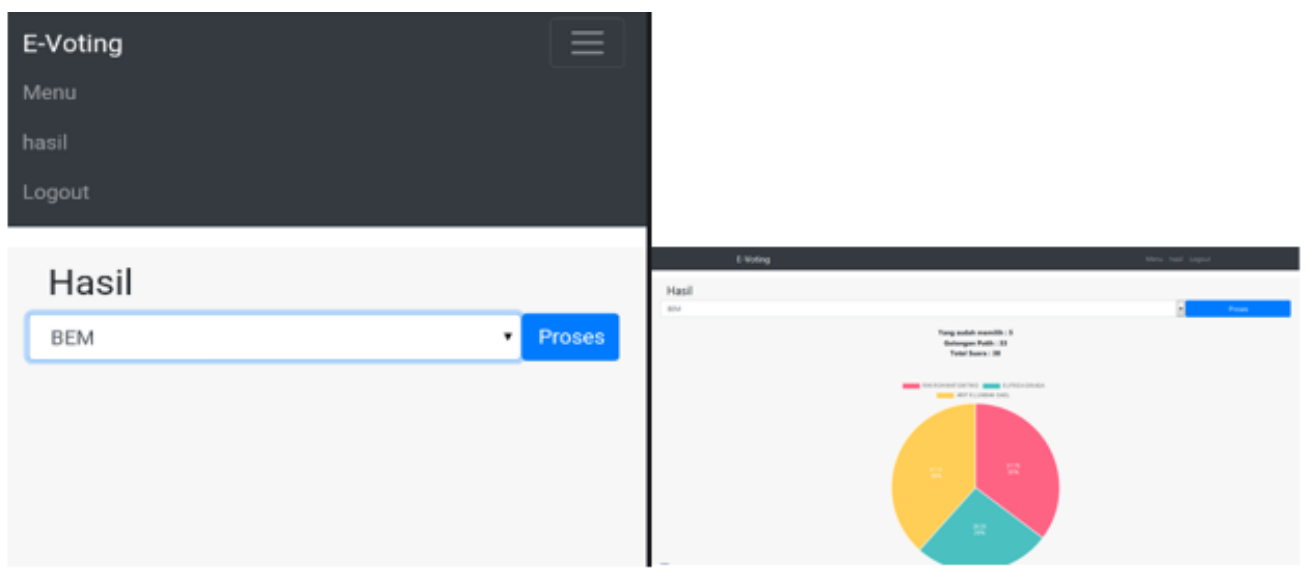

Gambar 15. Halaman Hasil Laporan

\section{KESIMPULAN}

Berdasarkan analisis dan hasil pembahasan dapat dirumuskan kesimpulan sebagai berikut:

1. Aplikasi E-Voting yang di bangun memudahkan Panitia Pemilihan Umum Mahasiswa (PPUM) dalam menyelenggarakan pemilihan BEM di Universitas Katolik Santo Thomas.

2. Dengan menggunakan metode Analytical Hierarchy Process (AHP) dalam aplikasi E Voting ini, mahasiswa di tuntun untuk menilai semua calon BEM berdasarkan kriteria yang sudah di tentukan

3. Mahasiswa dapat melakukan pemilihan BEM dimanapun berada dengan hanya menggunakan smartohone atau android.

Aplikasi yang dibangun masih memiliki banyak kekurangan, contohnya aplikasi E-Voting pemilihan BEM Universitas Katolik Santo Thomas berbasis android masih hanya dapat memilih Ketua Saja, di harapkan untuk selanjutnya dapat mengembangkan aplikasi yang dapat memilih Ketua dan Wakil Ketua BEM sekaligus dengan tetap menggunkan metode AHP.

\section{DAFTAR PUSTAKA}

[1] deepublihs, “Apa Itu BEM? Pengertian, Fungsi, Tujuan dan Tanggung Jawabnya,” deeppublish, Apr. $27,2020$. https://penerbitbukudeepublish.com/apa-itu-bem/ (accessed Nov. 11, 2020).

[2] Mubdimin, "Peran Badan Eksekutif Mahasiswa STIT Daussalimin NW Praya dalama mengembangkan Softskill Mahasiswa PAI," in STIT Darussalimin, vol. 53, no. 9, 2013, pp. 1689-1699.

[3] I. A. Pardosi and R. Purba, "Pengembangan Web E-Voting Menggunakan Secure Election Protocol," 2015. https://www.mikroskil.ac.id/ejurnal/index.php/jsm/article/view/180 (accessed Jun. 02, 2020).

[4] E. Priyono and F. N. Dihan, "E-Voting: Urgensi Transparansi \&amp; Akuntabilitas," Semin. Nas. Inform. Yogyakarta vol. 2010, no. 32, pp. 55-62, 2010, [Online]. Available: https://media.neliti.com/media/publications/175335-ID-e-votingurgensi-transparansi-dan-akunta.pdf.

[5] E. M. Pinayungan, "Sistem Informasi Kost Berbasis Android di Kota Medan," J. Tek. Inform. Unika St. Thomas, vol. 4 , no. 2, pp. 133-141, 2019.

[6] B. Das, E. Damanik, and W. Ginting, "Aplikasi Sistem Informasi Museum Negeri Provinsi Sumatera Utara Berbasis Android," KakifikomKumpulan Artik. Karya Ilm. Fak. Ilmu Komput., vol. 01, no. 2, pp. 67-72, 2019.

[7] T. Limbong et al., Sistem Pendukung Keputusan: Metode \& Implementasi. Yayasan Kita Menulis, 2020.

[8] Kusrini, Konsep dan Aplikasi Sistem Pendukung Keputusan. 2007.

[9] N. S. Eko Darmanto, Noor Latifah, "Penerapan Metode Ahp ( Analythic Hierarchy Process ) Untuk Menentukan Kualitas Gula Tumbu," Penerapan Metod. Ahp(Analythic Hierarchy Process. Menentukan Kualitas Gula Tumbu, vol. 5, no. ISSN: 2252-4983, pp. 75-82, 2014, doi: 10.1111/j.1744-7348.1952.tb00899.x.

[10] T. Limbong and J. Simarmata, "Menentukan Matakuliah yang Efektif Belajar Daring (Belajar dan Ujian) dengan Metode Multi-Attribute Utility Theory (MAUT),” J. Resti, vol. 4, no. 2, pp. 370-376, 2020.

[11] S. A. Sitorus and E. P. Malau, "Sistem Informasi Reservasi Hotel Pada GM. Marsaringar Balige Berbasis Android," MEANS (Media Inf. Anal. dan Sist., vol. 2, no. 1, pp. 52-57, Jun. 2017, doi: 10.17605/JMEANS.V2I1.24.

[12] S. N. Neyman, M. F. Isnaini, and S. Nurdiati, "Penerapan Sistem E-voting pada Pemilihan Kepala Daerah di Indonesia ( The Application of E-voting Systems in the Local Elections in Indonesia )," J. SainsTerapan, vol. 3, no. 1, pp. 45-61, 2013,

[Online]. Available: http://diploma.ipb.ac.id/uploads/images/jurnal/file/bf32d3694e8a57a3e5c45233889b1d52_Shelvie_NN_-

_Penerapan_Sistem_E-voting_pada_Pemilihan_Kepala_Daerah_di_Indonesia.pdf.

[13] Sugiyono, Metode Penelitian Kuantitatif, Kualitatif dan R\&D. Bandung: PT Alfabet, 2016.

[14] K. Chauhan, N. Shah, and R. Venkata Rao, "The Analytic Hierarchy Process as a Decision-Support System in the Housing Sector: A Case Study,” World Appl. Sci. J., vol. 3, Jan. 2008.

Rancang Bangun Aplikasi E-Voting Pemilihan Badan Eksekutif Mahasiswa Universitas Katolik Santo Thomas Berbasis Android. Oleh : Lena Siagian, Masdiana Sagala. 
[15] O. S. Vaidya and S. Kumar, “Analytic hierarchy process: An overview of applications,” Eur. J. Oper. Res., vol. 169, no. 1, pp. 1-29, 2006, doi: 10.1016/j.ejor.2004.04.028.

[16] S. Supriyono, "Sistem Penunjang Keputusan (SPK) Pemilihan Sepeda Motor Menggunakan Metode AHP," Simetris J. Tek. Mesin, Elektro dan Ilmu Komput., vol. 1, no. 1, p. 55, Jun. 2013, doi: 10.24176/simet.v1i1.116.

[17] T. Limbong, J. Simarmata, M. Rofendi Manalu, A. Rikki, and D. M. Rajagukguk, "Implementation of Multi Factor Evaluation Process (MFEP) in Assessment of Employee Performance Achievement," J. Phys. Conf. Ser., vol. 1573, no. 1, 2020, doi: 10.1088/1742-6596/1573/1/012022. 